\title{
Bull Semen Collection and Analysis for Artificial Insemination
}

\author{
Karolina Barszcz (Corresponding author) \\ Department of Morphological Sciences, Faculty of Veterinary Medicine \\ Warsaw University of Life Sciences, 159 Nowoursynowska Str., 02-776 Warsaw, Poland \\ Tel: 48-502-232-449 E-mail: karolina.barszcz@onet.eu \\ Dariusz Wiesetek \\ Student of Faculty of Veterinary Medicine \\ Warsaw University of Life Sciences
}

Tel: 48-727-524-187Ｅ-mail: darekwiesetek@tlen.pl

Michał Wąsowicz

Department of Morphological Sciences, Faculty of Veterinary Medicine

Warsaw University of Life Sciences, 159 Nowoursynowska Str., 02-776 Warsaw, Poland

Tel: 48-505-785-288Ｅ-mail: wasowiczm@gmail.com

Marta Kupczyńska

Department of Morphological Sciences, Faculty of Veterinary Medicine

Warsaw University of Life Sciences, 159 Nowoursynowska Str., 02-776 Warsaw, Poland

Tel: 48-602-666-309 E-mail: marta_kupczynska@sggw.pl

Received: March 3, $2011 \quad$ Accepted: March 17, $2011 \quad$ Online Published: December 29, 2011
doi:10.5539/jas.v4n3p1
URL: http://dx.doi.org/10.5539/jas.v4n3p1

\begin{abstract}
Insemination is acknowledged as a breeding method that contributes to improvement of farm animal populations, particularly of cattle. Artificial insemination allows for maximum use of the most valuable breeders and, at the same time, for significant increase of breeding advance. Moreover, using semen of proved quality reduces the spread of sexually transmitted diseases. The purpose of this study was to present the process of collection and analysis of bull's semen in the Mazovian Centre of Animal Breeding and Reproduction in Łowicz, Poland.
\end{abstract}

Keywords: Semen collection, Semen analysis, Bull semen

\section{Insemination}

In Poland, insemination has been performed for more than 50 years. The primary meaning of this term concerned introduction of sperm into the reproductive tract of a female for the purpose of impregnation. Nowadays this term includes: collection of semen, assessment of semen, preservation of semen, storage of semen, distribution of semen, insemination procedure $(1,9)$.

The bull becomes sexually mature at the age of approximately 9 months, however its reproductive role starts at the age of approximately 12 months. The semen of specimens below 18 months of age, used in artificial insemination, should contain at least:

- $60 \%$ of spermatozoa with correct progression

- $80 \%$ of spermatozoa without any morphological changes

- 500 thousand spermatozoa in $1 \mathrm{~mm}^{3}$. 
From specimens above 18 months of age the accepted ejaculate should contain $70 \%$ of spermatozoa with correct progression, whereas other features do not change (12).

The main factors influencing fertility include: the breed, breeding conditions and methods of use. Specimens between 2 and 7 years are the most fertile while in older ones a decrease in sperm production is observed. A correct breeding of a bull allows to its correct use. It is related to its breeding value, sperm quality, age and sexual activity. From mature specimens two ejaculates of semen are collected twice a week while from young bulls (up to 2 years) the ejaculates are collected every 5-7 days $(2,6,11)$.

The purpose of this study was to present the process of collection and analysis of bulls' semen in the Mazovian Centre of Animal Breeding and Reproduction in Łowicz, Poland.

\section{Assessment of the bull}

A careful selection of bulls ensures high quality specimens both from the reproductive and physical point of view. This includes requirements concerning physical fitness, condition of genital organs, semen and sexual behaviour. The physical fitness of a bull is evaluated in the standing position and in motion on hard ground, both in young and in mating specimens. Special attention should be paid to the position of thoracic limbs, pelvic limbs and the hoof build. Pelvic limbs are of basic importance for copulation efficiency because during mounting they take over the weight of the bull. Physical fitness is also necessary to evaluate. An analysis of the jump on a dummy female or a teaser is therefore performed.

The condition of genital organs is evaluated visually and tactilely as well as by per rectum examination. Male genital organs in bulls can be divided in two basic groups: internal genital organs and external genital organs. The internal genital organs include: specific testis, testicles producing male gametes - spermatozoa and reproductive tracts evacuating spermatozoa. The reproductive tracts are composed of parts located inside and outside the testicle. The former include the rete testis, the efferent ducts and the ductus epididymidis. The excretory ducts are the ductus deferens and ejaculatory duct. The internal genital organs also include accessory reproductive glands: the alveolar gland, the prostate gland and the bulbourethral gland. The external genital organs include the copulation organ - the penis - the male urethra and the scrotum.

The sexual behaviour is composed of several reactions conditioned by sex drive and the individually evoked sexual reaction. They can be subject to modifications due to the conditions of use, teaching or training. They are finally formed at the moment of sexual maturity. In the behaviour assessment two features are defined: the sex drive (libido) and the ability to copulate, which determine the reproductive usefulness of a bull.

The evaluation of the sex drive is performed at the moment of collecting the semen. Young bulls are induced to ejaculate into an artificial vagina after mounting a teaser (usually a specimen of low breeding value) or a dummy cow. In young bulls it evokes conditioned responses, which remain throughout their lives and induces their usefulness. It has to be underlined that bulls which have learnt to mate females in rut are reluctant to react sexually to a teaser or a dummy cow. Therefore specimens that are to be used in the insemination centre should not have been previously used in natural mating.

In the evaluation of the sex drive the reaction time of the bull to the teaser or dummy cow is considered. It is described on a six-degree scale as:

L-5 very strong - when the bull is allowed to enter the room it is spoiling for riding; the staff is unable to hold it still.

L-4 strong - the bull brought to the teaser or dummy cow starts to jump on it; the bull is calm and the staff is able to control it.

L-3 moderate - the bull brought to the teaser sniffs around it and after 2-3 minutes it starts to ride it.

L-2 weak - the bull sniffs around the teaser a few times and then mounts it. Before 10 minutes elapse the specimen repeats mounting during which it ejaculates.

L-1 very weak - during 10 minutes the bull does not mount the teaser, it only sniffs around. When the teaser is changed the bull ejaculates.

L-0 none - lack of interest; the bull does not sniff around and does not try to mount.

For the insemination centre only the specimens that demonstrate very strong, strong or moderate sex drive are useful. The assessment should be made repeatedly in order to exclude the bull's temporary indisposition (14).

The bulls' fertility is determined according to the following indices: 
- the non return index (NR) determines in percentage the number of animals inseminated for the first time, which were not submitted to another insemination in a given time,

- the insemination index determines the efficiency of insemination on the basis of the ratio of insemination procedures to the confirmed conceiving,

- calving index determines in percentage the number of females that had calves within the year compared to all females inseminated in this period,

- the conception rate determines the percentage of females impregnated after the first insemination or mating.

It also has to be noted that an optimal sexual activity in the reproduction period is guaranteed by well-balanced nutrition both from the energy and protein point of view. Excessive fatness of the animal affect negatively the liveliness of the sperm but protein deficiency decreases sexual activity and the quality of the sperm. Disorders in male reproduction may also be caused by vitamin deficiency (A, E, B-group vitamins) and lack of microelements (zinc, selenium, manganese, iodine) (11).

\section{Semen collection}

In the morning, before the collection of semen, the bull does not receive food because a full animal has lower sex drive. The collection of semen is performed in a specially prepared place called the "manege". The room must meet appropriate sanitary and health conditions because it is considered a laboratory room. The floor has to be flexible and anti-slip. In the first stage of the preparation the bull makes a few rounds in the "manege" and is allowed to sniff around and to jump other bulls and to perform empty jumps on a dummy cow. A well aroused male with distinctive sexual impulses is brought to the dummy cow or the teaser in order to produce semen (Fig. 1). The semen is collected in an artificial vagina composed of $(3,9)$ :

1 - a glass container for semen with a water jacket and a volume scale,

$2-$ a thin, flexible latex sleeve,

3 - a latex cone joining the end of the vagina with the collection tube,

4 - a rubber cylindrical casing with a valve for pouring water and blowing air,

5 - a bag - a thermal protector and a mechanical container (Fig. 2).

When the artificial vagina is installed attention has to be paid that:

- every ejaculate is collected in a separate vagina,

- the latex sleeve has to be installed in such a way that there are no folds inside the casing,

- the sleeve should be moderately stretched in order to pour water and blow air,

- the water temperature in vagina should be $40-42^{\circ} \mathrm{C}$,

- the temperature of the container should vary between $35-37^{\circ} \mathrm{C}$,

- the inlet to the vagina should be lubricat such as vaseline.

When collecting the semen attention must be paid that the bull does not touch the rump of the teaser with its penis. The person collecting the semen should take the bull's penis by the prepuce and direct it to the inlet of the vagina. The artificial vagina should never be put over the penis. Characteristically for its species, the bull performs a single copulation push. Next, the collected semen is evaluated.

\section{Analysis of fresh semen}

The semen is composed of spermatozoa and a liquid part called seminal plasma. The final composition of the semen depends on the level of development of accessory reproductive glands, the share of secretions from reproductive organs and the volume of spermatozoa in total. In the bull these secretions are the following: $50 \%$ secretion from alveolar glands, $25 \%$ secretion from bulbourethral glands, $7 \%$ secretion from the epididymis, $5 \%$ secretion from the prostate gland, $14 \%$ spermatozoa.

The chemical structure of the seminal plasma:

- water $90 \mathrm{~g} / 100 \mathrm{ml}$,

- protein $6.8 \mathrm{~g} / 100 \mathrm{ml}$,

- fructose 460 to $600 \mathrm{mg} \%$,

- sorbitol 10 to $140 \mathrm{mg} \%$,

- citric acid 620 to $800 \mathrm{mg} \%$, 
- glycerophosphocholine $350 \mathrm{mg} \%$,

- inositol 60mg\%.

The properties of the fresh semen of the bull are the following (Fig. 3):

- volume of the ejaculate 2 to $8 \mathrm{ml}$,

- colour: white with a characteristic cream hue,

- texture: milky, milk with cream, creamy,

- smell similar to cow's milk,

- spermatozoa concentration 0.6 to $1.5 \times 10^{6}$ in $\mathrm{mm}^{3}$,

-pH 6.2 to 6.8 (4).

In the volume evaluation, attention must be paid to the age of the male because the quantity of the collected semen in growing bulls increases with age. Decreased quantity of ejaculate may also suggest lack of preparation of the bull or mistakes committed during collection. A change in description parameters is usually a result of diseases of the urinogenital system. It usually concerns a change in colour. Pathological colours are the following:

- pink or red - suggest the presence of blood (which appears as the result of penis abrasion, fistulas of cavernous bodies, urinary stones),

- green - suggesting the presence of pus,

- yellow - suggesting the presence of urine,

- watery white - suggesting lower quantity of spermatozoa or water that got to the semen when collected from the artificial vagina.

Due to the presence of mucus resulting from inflammations of the urinogenital system, the texture may be more viscous. All impurities (fur, fertilizers, ground) are inacceptable. In the correct semen there are no deposits. If some deposit appears just after the collection, it may mean that a significant number of dead spermatozoa or inflammatory cells are present (14).

\subsection{Spectrophotometric analysis}

The first part of fresh semen evaluation is the spectrophotometric analysis (spectrophotometer - IMV Photometer) (Fig. 4). A sample of the semen $(0.02 \mathrm{ml})$ is diluted 1:200 with a physiological solution (Natrium Chloratum $0.9 \%$ ) and placed in a macro-cuvette. The result of the analysis is in the form of a print-out with the following information: analysis date, sample number, spermatozoon concentration, volume of the ejaculate, spermatozoon concentration in a straw, quantity of the necessary extender, number of straws received from the semen.

\subsection{Microscopic examination}

The second part of the fresh semen analysis is a microscopic examination (Nikon Eclipse E200 microscope with phase contrast and a heated stretching table). The samples of semen are placed on the table heated to $37^{\circ} \mathrm{C}$ and covered with a cover slip. In the first microscopic examination the progression of spermatozoon mass is analyzed (so-called "waving") with 50x zoom and with 200x zoom - the percentage of spermatozoa of general progression as well as the level of agglutination of the diluted semen (Fig. 5). The progression of the spermatozoon mass is called waving because it is induced by the progression of separate spermatozoa. The density of the semen affects the intensity of this progression. It is described on a six-degree scale as:

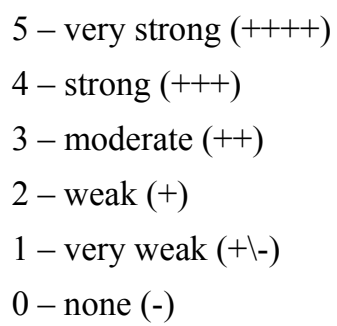

The semen used in artificial insemination should be characterized by at least moderate waving progression ( 7 , 14).

In the fresh semen analysis, the level of agglutination of spermatozoa is evaluated on a three level scale: 
A - weak agglutination

AA - moderate agglutination

AAA - strong agglutination

If numerous clusters of agglutinated spermatozoa are formed, the reproductive capability of the semen is limited (Fig. 6).

Spermatozoa observed in smears have a shape, defined as correct, particular for a specific species (Fig. 7). Apart from them there are also changed spermatozoa with disqualifying defects that are called incorrect forms $(10,13)$. In the morphological evaluation of the ejaculate the type and number of incorrect spermatozoa are determined in comparison to the total number of spermatozoa. The evaluation also determines the presence of other cells such as: leukocytes, erythrocytes, epithelial cells, etc. Due to the place of defect formation, two groups are distinguished:

I - primary changes formed during spermatogenesis and being the result of pathological processes in testicles,

II - secondary changes appearing after the spermatozoon is finally formed and it has left the testicles $(5,814)$.

In the classification used so far the pathological forms include (Fig. 8):

Main defects:

Handicapped spermatozoon

Double spermatozoon

Nodular spermatozoon

Headless spermatozoon

Sperm head with a halo

Pear-shaped spermatozoon

Spermatozoon with narrowed head base

Spermatozoon with an incorrect (blurred) outline

Spermatozoon with a small, incorrect head

Sperm head loose and incorrect

Spermatozoon with a corkscrew part

Spermatozoon with other defects of insertion (stump insertion)

Spermatozoon with a (proximal) protoplasmic droplet in the insertion

Spermatozoon with a pseudo-droplet of protoplasm in the insertion

Spermatozoon with severe tail abnormalities (Daga defect)

Secondary defects:

Spermatozoon with elongated head

Spermatozoon with a small but normal head

Spermatozoon with a wide and huge head

Loose but normal head

Spermatozoon with a separated acrosome membrane

Spermatozoon with an abaxial position of the head

Spermatozoon with a (distal) protoplasmic drop in the insertion

Spermatozoon with a single loop of tail

Spermatozoon with a loop at the end of the tail

Number of morphologically altered spermatozoa in fertile males should not exceed $15 \%$.

\section{Preservation of fresh semen}

In order to unify all collected ejaculates, a pre-dilution with BIOXcell IMV is performed up to $18 \mathrm{ml}$. The following process is cooling the pre-diluted ejaculate in a water bath (WSL Poland LWC). Initially the water temperature is $27^{\circ} \mathrm{C}$ and later it is $20^{\circ} \mathrm{C}$ (Fig. 9). Next, the quantity of the extender (BIOXcell IMV) at $20^{\circ} \mathrm{C}$ is measured out basing on the calculation from the spectrophotometric analysis. Then, the extender is added to the 
semen to properly dilute it. In the second microscopic examination in 200x zoom, the evaluation concentrates on the percentage of spermatozoa with correct progression and on their morphology in the fresh diluted semen. The evaluation considers only those spermatozoa featuring rapid and forward progression. Other forms of progression (circulating, backwards, oscillating) are assumed as incorrect. The evaluation scale of the forward progression of spermatozoa is as follows:

5 - almost all spermatozoa are moving (80-100\%),

4 - forward progression $(60-80 \%)$,

3 - forward progression (40-60\%),

2 - forward progression (20-40\%),

1 - forward progression shown by few spermatozoa (1-20\%),

0 - all the spermatozoa are still $(\mathrm{N})(7,14)$.

The next stage is to portion out the semen to mini-straws using a device for filling up and marking the samples (IS4 IMV) (Fig. 10). The label on every straw includes: breed symbol, bull's name and number, veterinary number of the centre, collection date and ejaculate number. After filling up the straws are controlled. The quantity, description and filling of the straws are verified. The straws that do not meet the requirements are disposed. The next stage of preservation is the equilibration of the bull's semen. The straws, put in frames, are placed into a cooler for 3.5 to 4 hours at the temperature of $4^{\circ} \mathrm{C}$. Then, they are put into a freezer (IMV) where, during 7 minutes, they are frozen to the temperature of $-140^{\circ} \mathrm{C}$ according to a programmed curve of freezing (Fig. 11). The frozen straws are stored in liquid nitrogen containers at the temperature of $-196^{\circ} \mathrm{C}$ (Fig. 12).

\section{Control of frozen semen}

The first control test of the frozen semen is performed in 1 to 3 days after freezing. 2 or 3 straws are randomly chosen from a given batch of semen. The semen has to flow automatically, therefore the straw is cut along the seal and then placed in a test-tube heated to approx. $37^{\circ} \mathrm{C}$. In a standard microscopic examination the percentage of spermatozoa with forward progression and their morphology are evaluated. After thawing, the bull's semen previously frozen in a straw should contain not less than:

- $50 \%$ of spermatozoa of correct progression,

- 6 million of spermatozoa of correct progression,

- $80 \%$ of spermatozoa without any morphological changes (12).

Another microscopic control of the semen is performed after 30 days of storage. When the semen receives positive notes, it is transported in containers to a semen bank from which it is distributed to animal insemination centres.

\section{Results of artificial insemination in the Masovian Centre of Animal Breeding and Reproduction in Lowicz}

Tabele 1 presents the quality of artificial insemination performed in the Mazovian Centre of Animal Breeding and Reproduction in Lowicz in 2006-2010 and their efficiency. During the period of 5 years the total of 2,4 million specimen where inseminated and the average efficiency amounted to $28.9 \%$.

\section{References}

Bourdon, R. M. (2000). Understanding Animal Breeding. ( $2^{\text {nd }}$ ed.). New Jersey: Prentice-Hall, 432.

Gamčik P., \& Sakala, J. (1971). Zaburzenia płodności u bydła [Fertility Disorders in Cattle]. Warszawa: PWRiL, pp. 110-112.

Głód W. (1976). Rozród i unasienianie bydła [Reproduction and Insemination in Cattle]. Warszawa: PWRiL, pp. 98-114.

Krzymowski T. (1998). Fizjologia zwierząt [Animal Physiology]. Warszawa: PWRiL, pp. 566-567.

Küst, D., \& Schaetz, F. (1972). Zaburzenia rozrodu zwierząt gospodarskich [Reproduction Disorders in Farm Animals]. Warszawa: PWRiL, pp. 147-148.

Litwińczuk, Z., \& Szulc, T. (2005). Hodowla i użytkowanie bydła [Cattle Breeding and Use]. Warszawa: PWRiL, pp. 193-196.

Monkiewicz J. (1995). Rozród zwierząt gospodarskich [Reproduction of Farm Animals]. Wrocław: AWR, pp. $85-102$. 
Noakes, D.E., Parkinson, T.J, \& England, G.C.W. (2009). Veterinary Reproduction and Obstetrics.London: Sounders Elsevier, pp. 750-760.

Peters, A.R., \& Ball, P.J.H. (1987). Reproduction in Cattle. London: Butterworth. pp. 52-74.

Rosłanowski K. (1987). Badanie i ocena przydatności rozpłodowej buhajów [Study and Assessment of Bull Reproductive Use]. Poznań: PWRiL, pp. 9-16.

Strzeżka J. (2007). Biologia rozrodu zwierząt. Biologiczne uwarunkowania wartości rozrodowej samca [Biology Reproduction of Animal. Biological Condition of Male Reproductive Value]. (vol. II). Olsztyn: UWM, pp. 133-157.

Ustawa z dnia 30 kwietnia $2004 \mathrm{r}$. w sprawie materiału biologicznego wykorzystywanego w rozrodzie zwierząt gospodarskich. Na podstawie art. 36 ustawy z dnia 20 sierpnia $1997 \mathrm{r}$. o organizacji hodowli i rozrodzie zwierząt gospodarskich (Dz. U. z 2002 r. Nr 207, poz. 1762 oraz z 2004 r. Nr 91, poz. 866) [Act of 30 April 2004 on biological material used in farm reproduction. Pursuant to Article 36 of the act of 20 August 1997 on organisation of farm animal breeding and reproduction].

Wierzbowski, S. (1996). Andrologia [Andrology]. Kraków: PLATAN, pp. 23-25.

Wierzbowski, S., \& Żukowski, K. (2007). Rozród bydła [Cattle Reproduction]. Balice: KOS, pp. 127-133.

Table 1. Insemination results according to years in the Masovian Centre of Animal Breeding and Reproduction in Łowicz, Poland

\begin{tabular}{|c|c|c|c|c|c|}
\hline Year & Insemination I & Insemination II & Insemination III & Insemination IV & \% of repetitions \\
\hline 2006 & 521554 & 151161 & 46691 & 24613 & 28,98 \\
\hline 2007 & 512566 & 152425 & 48699 & 27191 & 29,74 \\
\hline 2008 & 486812 & 139999 & 44993 & 27446 & 28,76 \\
\hline 2009 & 457703 & 129745 & 41732 & 25349 & 28,35 \\
\hline 2010 & 440175 & 126289 & 41562 & 24806 & 28,69 \\
\hline
\end{tabular}

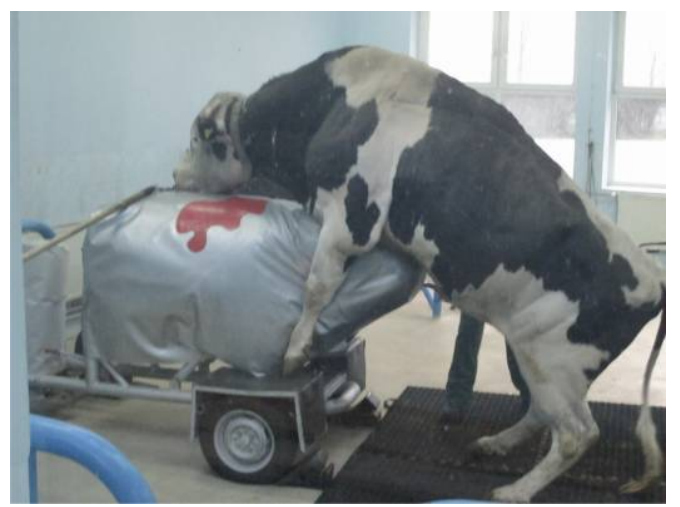

Figure 1. Jump on a dummy cow - semen collection

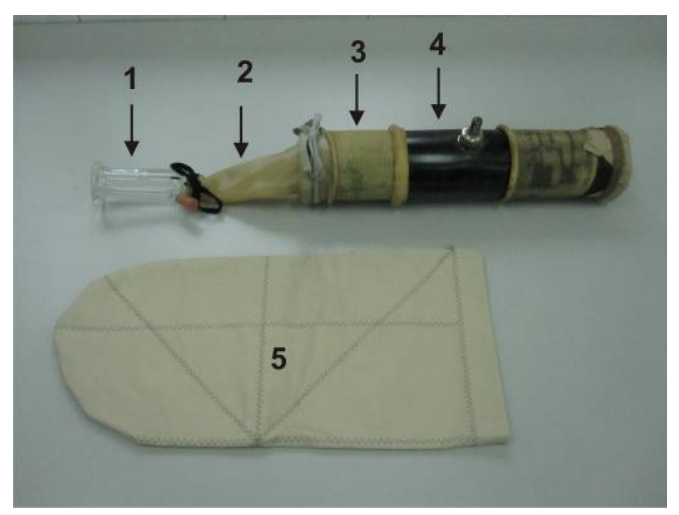

Figure 2. Structure of an artificial vagina. 


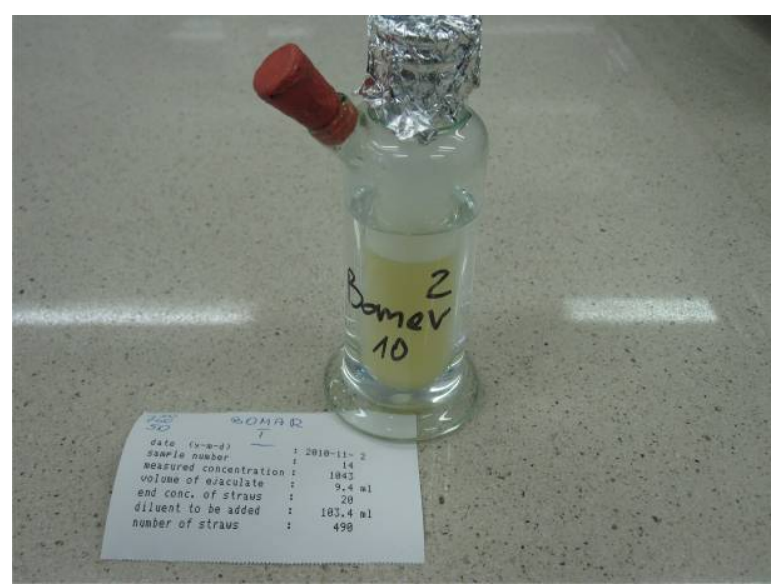

Figure 3. The fresh semen of the bull

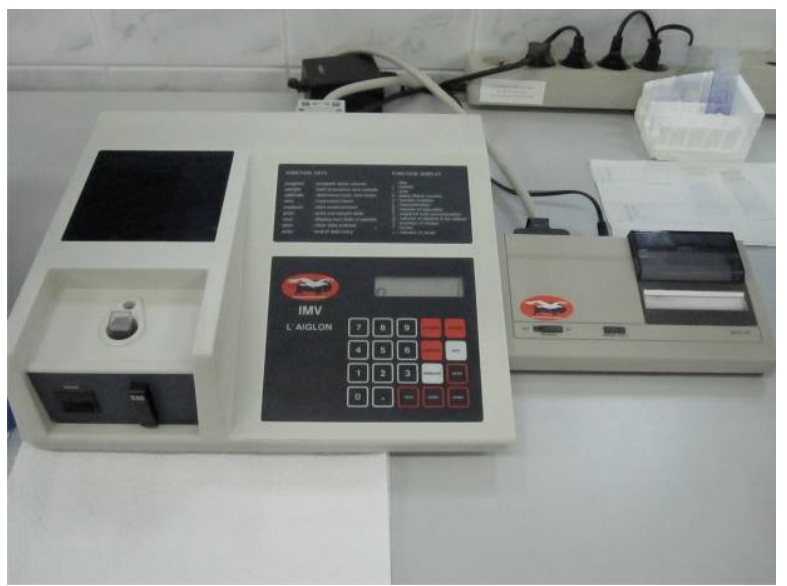

Figure 4. Spectrophotometric analysis of fresh semen sample

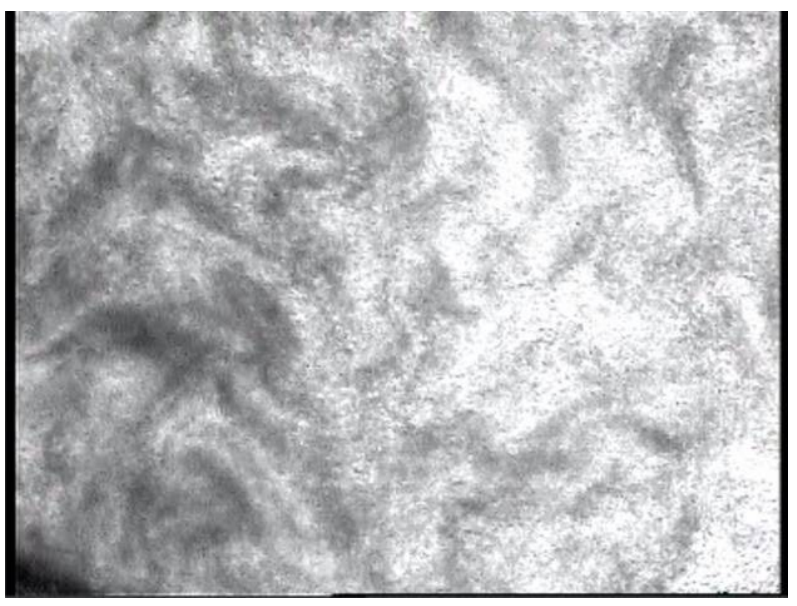

Figure 5. Microscopic examination - the progression of spermatozoon mass (x50) 


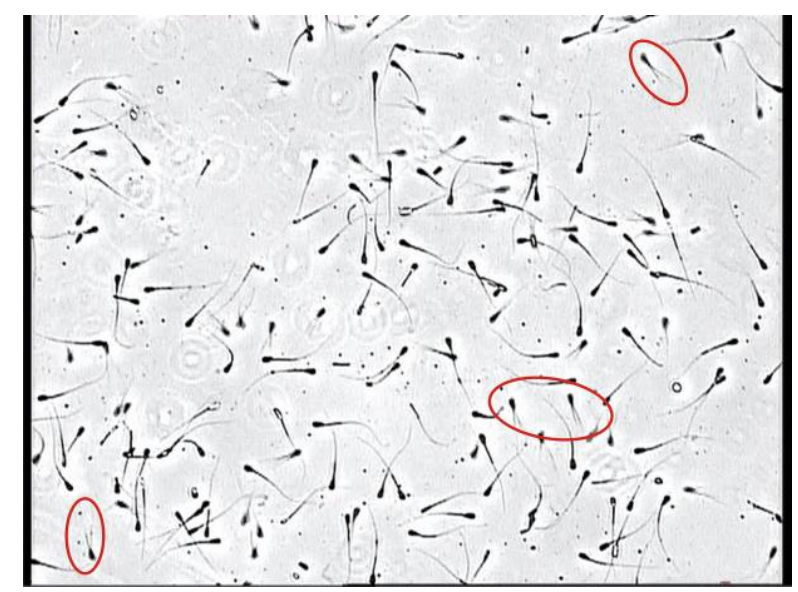

Figure 6. Microscopic examination - the level of agglutination of spermatozoa (x200)

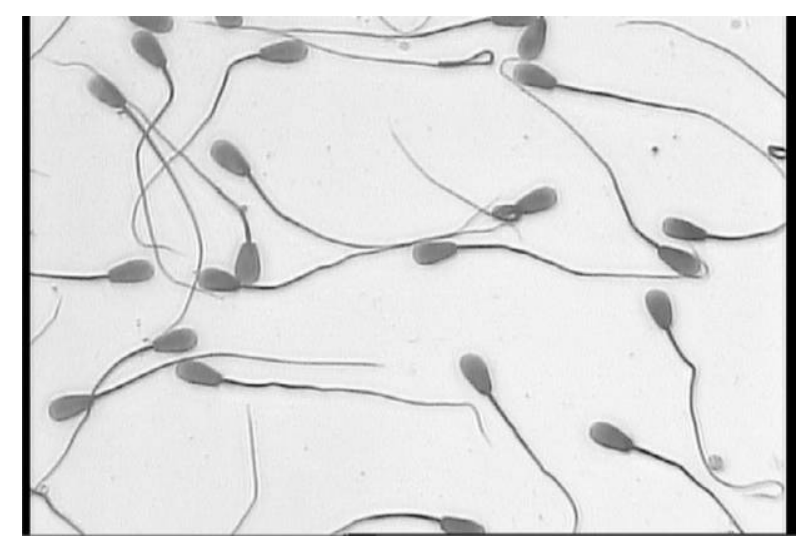

Figure 7. Microscopic examination - the morphological evaluation of spermatozoa (x200)

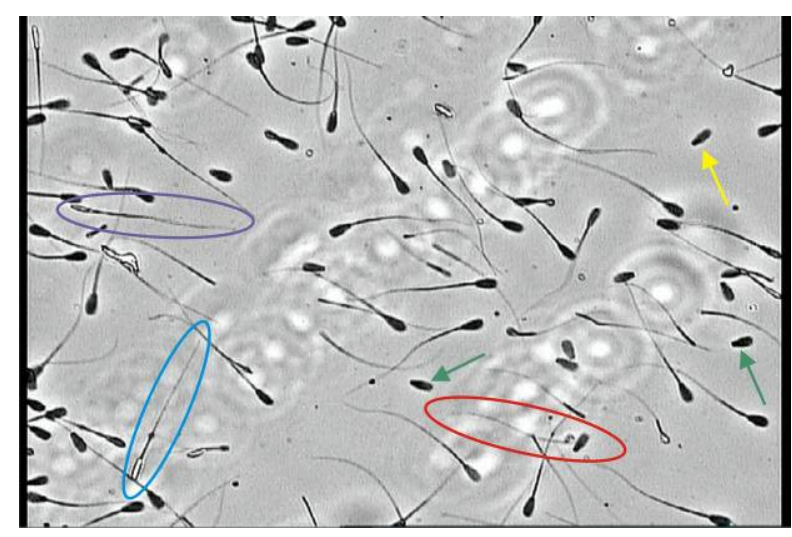

Figure 8. Chosen defects of spermatozoon: violet ellipse - spermatozoon with a small, incorrect head; blue ellipse - spermatozoon with a (distal) protoplasmic drop in the insertion; red ellipse - headless spermatozoon; yellow arrow - sperm head loose and incorrect; green arrow - loose but normal head 


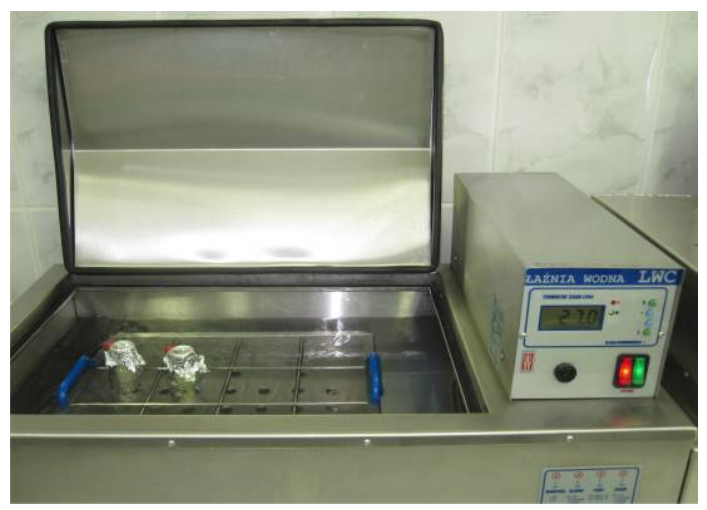

Figure 9. Water bath - process of cooling the pre-diluted ejaculate

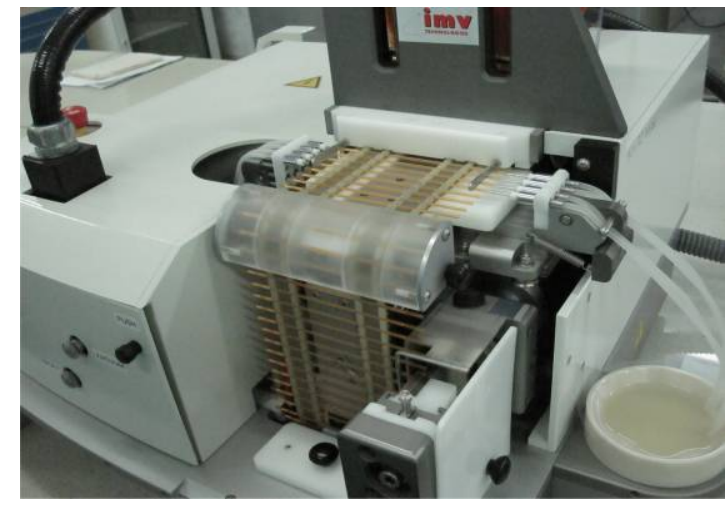

Figure 10. Portion out the semen to mini-straws

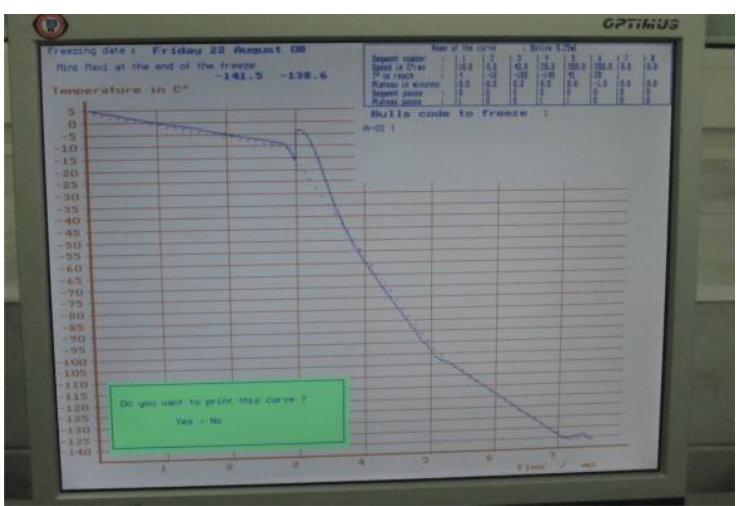

Figure 11. The programmed curve of freezing

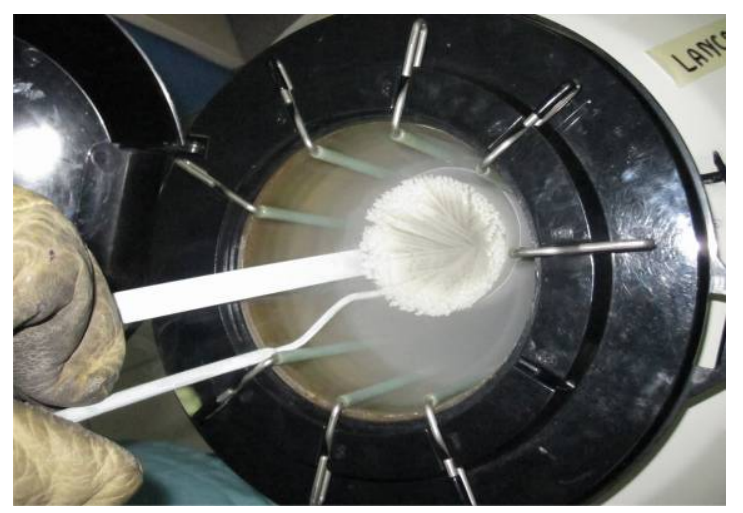

Figure 12. Container with the frozen straws 